\title{
DINAMIKA POPULASI IKAN TUNA ALBAKORA (Thunnus alalunga Bonnaterre, 1788) YANG DIDARATKAN DI PELABUHAN PERIKANAN NUSANTARA (PPN) PRIGI KABUPATEN TRENGGALEK, JAWA TIMUR
}

\section{FISH POPULATION DYNAMIC OF ALBACORE TUNA (Thunnus alalunga Bonnaterre, 1788) LANDED IN PRIGI ARCHIPELAGO FISHING PORT TRENGGALEK REGENCY, EAST JAVA}

\author{
Tri Djoko Lelono", Gatut Bintoro, dan Didik Rudianto \\ Fakultas Perikanan dan Ilmu Kelautan, Universitas Brawijaya, Malang
}

Jalan Veteran, Ketawanggede, Lowokwaru, Ketawanggede, Kec. Lowokwaru, Kota Malang, Jawa Timur 65145

E-mail: t.djoko@ub.ac.id

(Diterima: 18 Desember 2018; Diterima setelah perbaikan: 16 Januari 2019; Disetujui: 16 Januari 2019)

\begin{abstract}
ABSTRAK
Tuna albakora (Thunnus alalunga) merupakan salah satu jenis tuna yang ditemukan di perairan Indonesia. Penelitian terhadap aspek dinamika popukasi tuna albakora masih jarang dan perlu dilakukan pengkajian dalam upaya pengendalian stok. Tujuan penelitian ini adalah untuk mengetahui hubungan panjang berat dan aspek dinamika populasi yang meliputi pendugaan kelompok umur, parameter pertumbuhan (L”, K, dan to), laju mortalitas, laju eksploitasi, rekrutmen, analisa yield per recruit (Y/R) dan biomassa per recruit (B/R) pada ikan tuna albakora (T. alalunga). Penelitian dilaksanakan di Pelabuhan Perikanan Nusantara (PPN) Prigi, Kabupaten Trenggalek, Jawa Timur pada bulan Agustus-Desember 2016. Metode yang digunakan adalah metode deskriptif analitik dengan 2.702 sampel ikan. Hasil penelitian menunjukkan bahwa pertumbuhan ikan bersifat allometri negatif dengan nilai $b<3$. Parameter pertumbuhan Von Bertalanffy didapatkan hasil L" $=118,3 \mathrm{~cm}$ FL dan $\mathrm{K}=0,51$ year. Nilai to diketahui dengan menggunakan persamaan Pauly (1984) dihasilkan to $=-0,219$ tahun. Nilai Lc dan Lm masing-masing sebesar 101,61 cm FL dan $90 \mathrm{~cm}$ FL. Nilai laju mortalitas total $(\mathrm{Z})$ tuna albakora $=1,81$, laju mortalitas alami $(\mathrm{M})=0,8$ laju mortalitas penangkapan $(F)=1,01$, laju eksploitasi $(E)=0,56$ atau $56 \%$, nilai yield per recruit $(Y / R)=0,029$ per tahun dan biomassa per recruit $(\mathrm{B} / \mathrm{R})=0,349$ per tahun.
\end{abstract}

KATA KUNCI: Hubungan panjang berat; Ukuran pertamana kali tertagkap (Lc); Ukuran pertama kali matang gonad $(\mathrm{Lm})$; Parameter Von Bertalanffy growth

\begin{abstract}
Albacore tuna (Thunnus alalunga) is one of tuna species found in Indonesia. Research on population dynamics aspects of albacore tuna is rarely done and need to be conducted in the effort of stock control. The purpose of this research is to identify length weight relationship and the aspects of population dynamics including of age groups estimation, growth parameters (L”, $\mathrm{K}$, and to), mortality rate, exploitation rate, recruitment, yield per recruit $(\mathrm{Y} / \mathrm{R})$ and biomass per recruit $(\mathrm{B} / \mathrm{R})$ of albacore tuna (T. alalunga). The research was conducted at Prigi Archipelago Fishing Port, Trenggalek Regency, East Java during August to December 2016. The research used analytical descriptive method with 2,702 fish sample. Results showed that fish growth was negative allometric with $b<3$. Von Bertalanffy growth parameters analysis gave result L" $=118.3 \mathrm{~cm}$ FL and $\mathrm{K}=0,51 /$ year. The value to was calculated by using the Pauly equation (1984) which generated to $=-0.219$ year. The values of $\mathrm{Lc}$ and $\mathrm{Lm}$ were $101.61 \mathrm{~cm}$ FL and $90 \mathrm{~cm}$ FL respectively. Total
\end{abstract}

\footnotetext{
\# Korespondensi: Universitas Brawijaya

E-mail: t.djoko@ub.ac.id
} 
mortality $(\mathrm{Z})$ of tuna albakora $=1.81$, natural mortality $(\mathrm{M})=0.8$ fishing mortality $(\mathrm{F})=1.01$, exploitation rate $(E)=0.56$ or $56 \%$, yield per recruit $(Y / R)=0.029$ per year and biomass per recruit $(B / R)=0.349$ per year.

KEYWORDS: length weight relationship; lenght Capture (Lc); Lenght maturite (Lm); Von Bertalanffy growth parameters

\section{PENDAHULUAN}

Tuna adalah predator laut pada posisi paling tnggi di laut dan berperan penting dalam memainkan ekosistem laut.Terdapat tujuh spesies tuna yang penting bagi ekonomi internasional antara lain tuna albakora (T. alalunga), tuna mata besar (T. obesus), tuna sirip biru Atlantik (T. thynnus), tuna sirip biru Pacifik (T. orientalis), tuna sirip biru selatan ( $T$. maccoyii), tuna sirip kuning (T. albacares) dan cakalang (Katsuwonus pelamis). Sedangkan untuk Albacore tuna (Thunnus alalunga) adalah ikan yang sangat bermigrasi yang ditemukan di perairan tropis dan subtropis disetiap cekungan yang ada di laut (Arrizabalaga et al., 2015; Collette dan Nauen, 1983).Thunnus alalunga (Bonnaterre, 1788) (Teleostei: Scombridae) memiliki sifat distribusi migrasinya di seluruh daerah tropis dan subtropis dari semua samudera, termasuk Laut Mediterania (Collette dan Nauen, 1983). Spesies ini merupakanpemangsa tingkat atas, dan pola makannya bervariasi menurut ukuran dan ketersediaan yang di mangsa, misal .pilchard, ikan teri, mackerel, cumi dan krustasea (Consoli et al., 2008). Namun Populasi ikan tuna ini di perairan laut pengelolaan berbeda dan sebagai stok terpisah, hal ini dibuktikan berdasarkan pemisahan geografis, lokasi daerah penangkapan dan musim pemijahan yang berbeda (Alonso et al., 2005; Joseph, 2003). Lebih lanyut Albaina et al., 2013) menyatakan bawah ikan tuna dalam siklus hidupnya bermigrasi yang sangat jauh, sertapenyebaran yang sangat luas, ada di Samudra Atlantik, India dan Pasifik. Ada populasi Thunnus maccoyii yang mendiami di laut selatan, dan biasanya terdapat satu atau dua populasi tuna tropis dan subtropis di seluruh samudra, kecuali untuk albacore yang memiliki 3 populasi di Atlantik. Berdasarkan sifat migrasi yang luas maka dalam pengelolaan perikanan tuna terdapat organsasi yang dikenal tuna Regional Fisheries Management Organization (tRFMO) dengan tujuan tujuan utama menjaga produktivitas setiap stok secara maksimal, meskipun dalam beberapa tahun terakhir telah ada upaya menuju pelaksanaan Pendekatan Ekosistem untuk Manajemen Perikanan (EAFM) (Arrizabalaga Haritz et, al 2015).

Tingginya tingkat eksploitasi populasi tuna selama 20 tahun terakhir telah menyebabkan keprihatinan yang luas atas status populasi tuna (Sibert et al., 2006). Tuna adalah hewan yang sangat mobile yang diklasifikasikan sebagai sangat bermigrasi di bawah hukum internasional. Mereka biasanya menempati seluruh wilayah samudera, tetapi populasi mereka tidak terdistribusi secara seragam dan juga tidak ada seragam perikanan tuna dalam ruang dan waktu. Pergerakan pada semua skala dimediasi oleh kondisi lingkungan. Oleh karena itu, model populasi tuna harus termasukpopulasi temporal dan dinamika spasial, dan dinamika ketergantungan pada lingkungan memaksa untuk aplikasi untuk manajemen perikanan (Sibert dan Hampton, 2003).

Dinamika populasi ikan merupakan kelanjutan dari biologi perikanan yang mempelajari pergerakan (perubahan - parubahan dasar yang terjadi dalam populasi seperti kecepatan mortalitas, rekruitmen dan pertumbuhan) serta menerapkan prinsip pengelolaan sumberdaya perikanan yang rasional umumnya bersifat kuantitatif sehingga ketepatan data yang digunakan untuk penelitian sangat berpengaruh dalam menghasilkan suatu kesimpulan. Salah satu kegiatan pemanfaatan sumberdaya ikan yaaitu dengan melakukan penangkapan ikan yang bersifat dapat pulih kembali (recovery), tanpa adanya dampak yang dapat merugikan untuk keseimbangan alam pada waktu yang akan datang. Dengan penelitian yang membahas tentang biologi ikan, dinamika populasi ikan serta pola rekruitmen maka akan dapat mengetahui tingkat eksploitasi dan pengelolaan sumberdaya perikanan, yang pada akhirnya nanti dapat mengklasifikasikan status pengelolaan stok tersebut. Sehingga tindakann terhadap status pengusahaan sumberdaya perikanan tersebut sesuai dengan sasaran yang diinginkan.

\section{BAHAN DAN METODE}

Data yang digunakan dalam penelitian ini hasil tangkapan yang didaratkan di Pelabuhan Perikanan Nusantara (PPN) Prigi, Kabupaten Trenggalek, Jawa Timur pada bulan Juli-Desember 2016 .Data primer yang diambil dalam penelitian ini adalah data panjang cagak (Fork Length) dan berattubuh dari sampel ikan tuna albakora sebanyak 2.702 ekor yang tertangkap pada alat tangkap pancing tondadi Pelabuhan Perikanan Nusantara Prigi, Kabupaten Trenggalek.

\section{Analisis Data}

Analisis menggunakan software aplikasi FISAT II (FAO ICLARM ASSESMENT TOOLS) (Goyalino et al 
2005) sedangkn untuk menganalisis data yang lainnya dan pengoreksian data yang diperoleh dilakukan dengan menggunakan software Microsoft Excel.Analisis hubungan panjang berat, panjang ikan dikonversikan kedalam berat dengan menggunakan fungsi berpangkat (Pauly,1983) yaitu:

$$
\mathrm{W}=\mathrm{a} \cdot \mathrm{L}^{\mathrm{b}}
$$

Keterangan :

W : berat tubuh ikan (gram) ;

L : Panjang tubuh ikan $(\mathrm{cm})$;

a dan $\mathrm{b}=$ Konstanta

Uji t dilakukan terhadap nilai b untuk mengetahui apakah nilai b sama dengan 3 (pola pertumbuhan isometric) atau tidak sama dengan 3 (pertumbuhan allometrik). Uji t menggunakan rumus menurut Effendi tahun 2002 sebagai berikut:

$$
\mathrm{t}=\frac{3-\mathrm{b}}{\mathrm{Sb}}
$$

Keterangan:

$\mathrm{t}$ : $\mathrm{t}$ hitung

b : konstanta

$\mathrm{Sb}:$ Standart deviasi

Kemudian nilai thitung akan dibandingkan dengan nilai t tabel dengan selang kepercayaan 95\%. Jika $t$ hitung $<\mathrm{t}$ tabel maka terima hipotesis nol sedangkan jika t hitung $>$ t tabel maka tolah hipotesis nol. Dari uji t hipotesis adalah sebagai berikut:

$\mathrm{HO}: \mathrm{b}=3$, hubungan panjang dengan berat adalah isometric

$\mathrm{H} 1$ : b ““ 3 , hubungan panjang dengan berat adalah allometris

\section{a. Kelompok umur}

Pendugaan kelompok umur (kohort) menggunakan metode Bhattacharya pada program aplikasi FISAT II. Pada masing-masing waktu pengambilan sampel, dilakukan plot data dengan menentukan titik tertinggi dan titik terendah pada data yang ditampilkan yang memungkinkan merupakan kohort. Kemudian menganalisis nilai $\mathrm{R}^{2}$, standart deviasi dan mean yang ada pada hasil plot data.

\section{b. Pertumbuhan}

Pendugaan parameter pertumbuhan dilakukan dengan menggunakan rumus pertumbuhan Von Bertalanffy (Sparre \& Venema, 1996) sebagai berikut:

$$
\mathrm{Lt}=\mathrm{L} \infty\left(1-\mathrm{e}^{-\mathrm{k}(\mathrm{t}-\mathrm{t} 0)}\right)
$$

dari persamaan pertumbuhan von Bertalanffy, maka rumus dapat dimanipulasi menjadi:

$$
\partial=\mathrm{L} \infty(1-\mathrm{b})
$$

sebab K dan L" adalah konstanta, a dan juga b menjadi konstanta jika $\Delta \mathrm{t}$ adalah sebuah konstanta. Parameter pertumbuhan k dan L" berasal dari:

$$
\mathrm{k}=\frac{-1}{\mathrm{t}} \ln \mathrm{b} \quad \mathrm{L} \infty=\frac{\mathrm{a}}{1-\mathrm{b}}
$$

Selanjutnya untuk menentukan $\mathrm{t}_{\mathrm{o}}$ digunakan rumus Pauly (1983), yaitu:

$\log \left(-t_{0}\right)=-0,3922-0,2752(\log L \infty)-1,038(\log k)$

Dimana:

L" : Panjang asimptot ikan $(\mathrm{cm})$

$\mathrm{K}$ : Koefisien laju pertumbuhan (tahun)

$\mathrm{t}_{\mathrm{o}}$ : Umur teoritis ikan pada saat panjang sama dengan nol (tahun)

\section{c. Pendugaan Mortalitas}

Menurut Pauly (1983), kematian alami pada ikan uga dipengruhi oleh suhu lingkungan. Berbagai keterkaitan dapat dilihat dari data pertumbuhan panjang dengan regresi berganda.

$$
\begin{aligned}
\log M= & -0,0066-0,279 \log \mathrm{L} \infty+0,6543 \log \mathrm{K} \\
& +0,4634 \log \mathrm{T}
\end{aligned}
$$

\section{Keterangan:}

$\mathrm{M}=$ Laju mortalitas alami (tahun)

L" = Panjang asimptot ikan $(\mathrm{cm})$

$\mathrm{K}=$ Koefisien pertumbuhan

$\mathrm{T}=$ Suhu rata - rata permukaan $\left({ }^{\circ} \mathrm{C}\right)$

Menurut Sparre \& Venema (1996), informasi mengenai laju kematian adalah sangat penting dalam menganalisis dinamika suatu populasi yang dieksploitasikan dan besarnya stok. Laju kematian dapat diduga dengan menggunakan persamaan yang dikemukakan oleh Beverton dan Holt. Mortalitas total dapat diduga dengan rata - rata panjang (L) hasil tangkapan suatu populasi ikan, dengan persamaan sebagai berikut: 


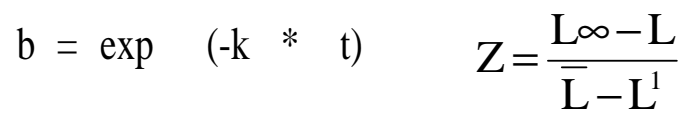

Dimana :

Z : Laju mortalitas alami

$\mathrm{K}$ : Koefisien laju pertumbuhan

L" : Panjang asimptot ikan $(\mathrm{cm})$

$\mathrm{L}$ : Panjang rata -rata ikan yang tertangkap

$1=$ Batas terkecil ikan yang tertangkap

Menurut Pauly (1983), untuk menghitung laju tingkat eksploitasi (eksploitation ratio) digunakan rumus sebagai berikut :

$$
E=\frac{F}{F+M} \quad Z=M+F
$$

Dimana :

E : laju tingkat eksploitasi (exploitation rate)

F : mortalitas penangkapan (fishing mortality)

$\mathrm{M}$ : mortalitas alamiah (natural mortality)

$\mathrm{Z}:$ mortalitas total (total mortality)

\section{d. Rekrutmen}

Penentuan pola rekrutmen dikerjakan menggunakan program aplikasi FISAT II. Pola ini ditentukan dengan menggunakan data frekuensi panjang yang telah ditetapkan. Untuk memperoleh plot pola rekrutmen berdasarkan waktu dibutuhkan parameter-parameter pertumbuhan yang sebelumnya telah diperoleh dari model von Bertalanffy dan Gulland Holt. Nilai L", $\mathrm{K}$ dan t0 merupakan nilai input yang digunakan dalam pengerjaan penentuan pola rekrutmen pada program aplikasi FISAT II.

\section{e. Yield perRecruit dan Biomass perRecruit}

Pendugaan $Y / R$ dan $B / R$ dapat dilakukan dengan program FISAT II dengan mengklik asses - Beverton dan Holt $\mathrm{Y} / \mathrm{R}$ analysis - knife edge. Sehinga didapatkan gambar $\mathrm{Y} / \mathrm{R}$ dan $\mathrm{B} / \mathrm{R}$ dengan memasukan nilai $\mathrm{M} / \mathrm{K}$ maka didapatkan gambar yang sesuai dengan penelitian yang kita lakukan, dalam gambar tersebut terdapat warnawarna, yang pada setiap warna menunjukkan nilai yang berbeda-beda.

\section{HASIL DAN PEMBAHASAN}

\section{Hubungan Panjang dan Berat}

Berdasarkan gambar 1diketahui bahw selama bulan Juli-November 2016 tuna albakora memiliki sifat pertumbuhan alometrik negatif dan memiliki karena nilai $b<3$. Hal ini diduga dipengaruhi oleh daerah penangkapan (rumpon) yang berbeda dan memungkinkan memiliki kondisi perairan seperti kelimpahan makanan dan suhu yang berbeda. Selama penelitian, pengamatan suhu melalui Ocean Colour (2016) didapatkan hasil pada bulan Juli $29,18^{\circ} \mathrm{C}$, Agustus $28,44^{\circ} \mathrm{C}$, September $28,23^{\circ} \mathrm{C}$, Oktober $28,90^{\circ} \mathrm{C}$ dan November $29,75^{\circ} \mathrm{C}$. Nilai b dipengaruhi oleh perilaku ikan, misalnya aktif berenang (kebanyakan ikan pelagis) , lokasi daeaah penangkapan i energi untuk pergerakan dan pertumbuhan. Kemungkinan adanya populasi albakora yang berbeda secara genetis di Samudera Hindia, konsep metapopulasi didefinisikan sebagai suatu populasi lokal yang memiliki habitat berbeda namun terhubung satu sama lain dengan migrasi untuk tujuan pemijahan dan makan (Dhurmeea et al., 2016).

\section{Aspek Dinamika Populasi}

\section{a. Pendugaan Kelompok Umur}

Stok terdiri dari individu-individu dari kohort yang berbeda dan akibatnya usia dan ukuran juga berbeda. Hal tersebut sering digunakan dalam menganalisis dan memproyeksikan stok untuk ditangkap pada tahuntahun mendatang, dengan mengikuti evolusi kohort yang berbeda. Sebuah kohort atau kelas tahunan atau satu generasi adalah sekelompok individu yang lahir di musim pemijahan yang sama (Cadima, 2003). Berdasarkan hasil analisis batacharya dalam pemisahan klas panjang (gambar 2) hasil tangkap berdasarkan hasil analisis menunjukkan ada yanng satu kohort atau lebih dari satu kohort.

Menurut Sparre \& Venema (1996), banyak ikan tropis yang memijah paling tidak dua kali dalam setahun dan sering dalam masa yang panjang. Karena ada perubahan angin secara periodik (angin muson) dan pergantian kondisi oseanografi (up welling) dibanyak daerah tropis, suatu tingkat gejala musiman tertentu masih dapat ditemui. Gejala musiman ini dapat terlihat pada pola pemijahan dan pertumbuhan jenis ikan tropis walaupun kurang jelas dan lebih sulit dibandingkan dengan ikan iklim sedang. Perbedaan musiman ini memungkinkan pula untuk menentukan adanya berbagai kohort (sering dua kohort pertahun) pada ikan tropis melalui analisis contoh frekuensi panjang.

\section{b. Parameter Pertumbuhan}

Parameter pertumbuhan Von Bertalanffy (L" dan K) didapatkan dari hasil pengolahan data sebaran frekuensi panjang melalui FISAT II yaitu L" = 118,3 $\mathrm{cm} F L$ dan $\mathrm{K}=0,51 /$ year. Kemudian nilai $\mathrm{t}_{\mathrm{o}}$ dapat diketahui dengan menggunakan persamaan Pauly (1984) yaitu $\log \left(-\mathrm{t}_{\mathrm{o}}\right)=-0,3922-0,2752 \log (\mathrm{L}$ ')-1,038 $\log (\mathrm{K})$ sehingga dihasilkan nilai $\mathrm{t}_{\mathrm{o}}$ sebesar $-0,219$. 

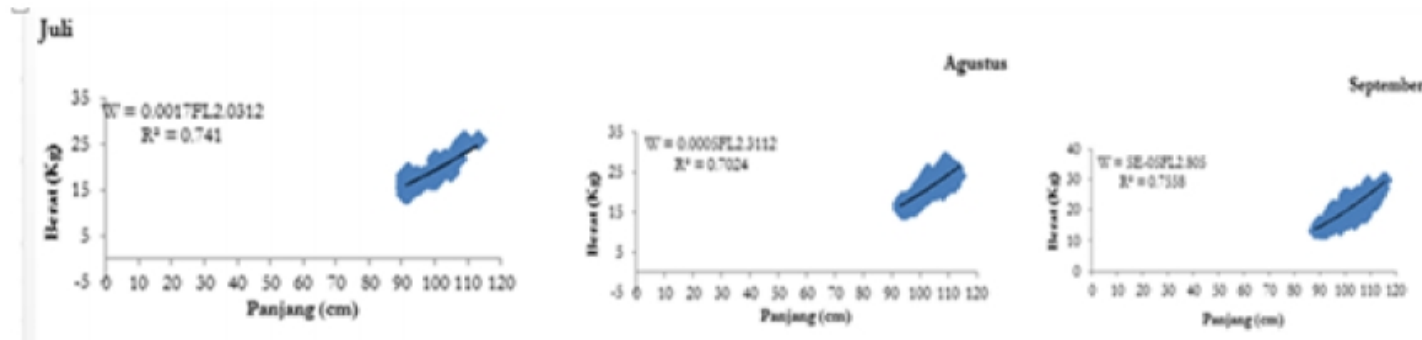

Norembet
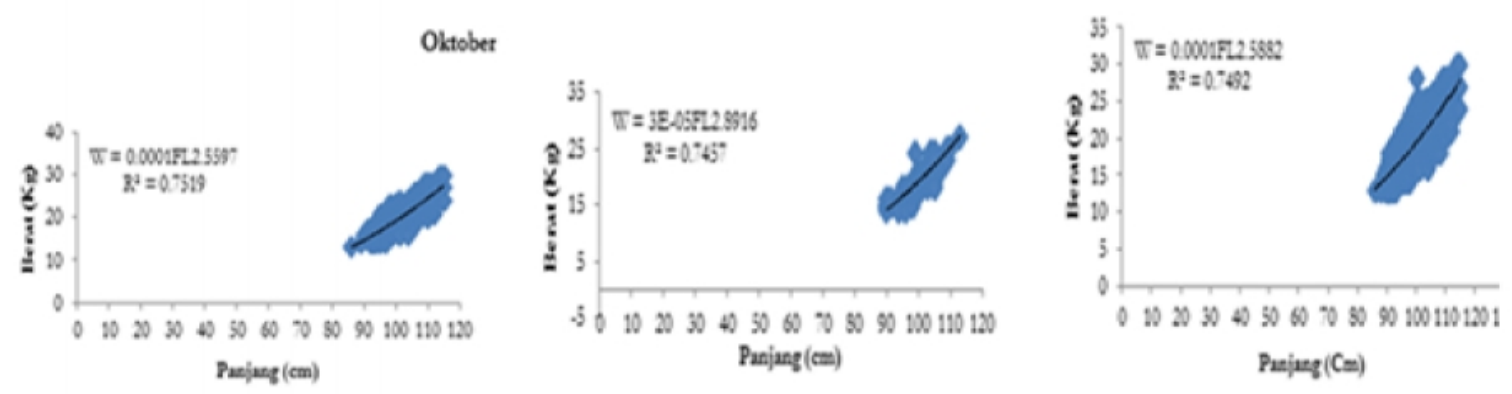

Gambar 1. Hubungan panjang dan berat tuna albakora bulan Juli - Desember 2016.

Figure 1. Relationship between the length and weight of albakora tuna in July - desember 2016.
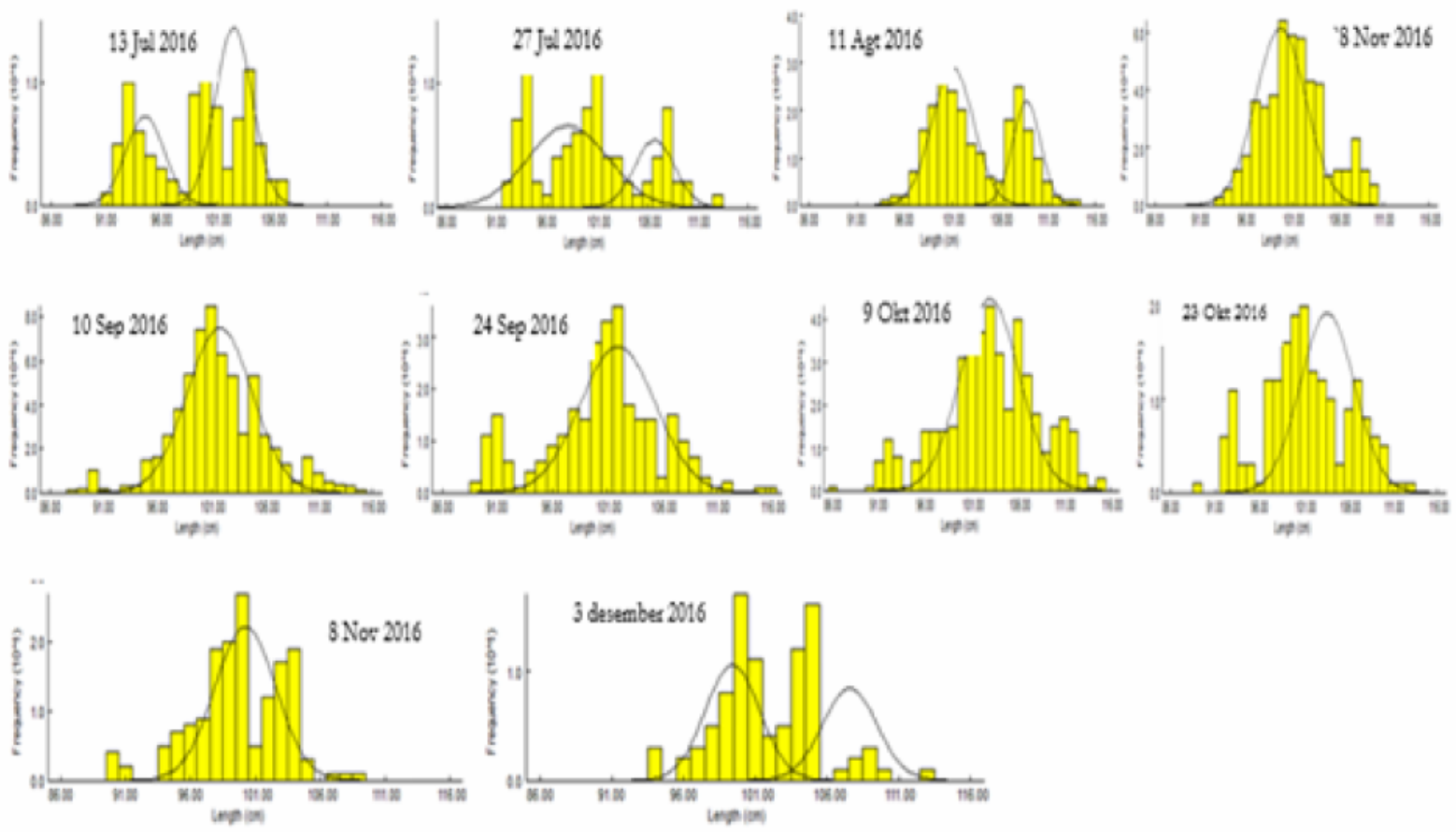

Gambar 2. Kelompok umur (kohort) tuna albakora.

Figure 2. Age group (cohort) of albacora tuna. 
Setelah nilai $\mathrm{L}$, $\mathrm{K}$ dan $\mathrm{t}_{\mathbf{o}}$ diketahui, maka didapatkan persamaan pertumbuhan panjang Von Bertalanffy untuk tuna albakora adalah $\mathrm{L}_{\mathrm{t}}=118,3(1-\exp (-0,51(\mathrm{t}+0,219))$ (Gambar 3). Model pertembuhan ikan merupakan satu salah komponen yang dalam penilaian stok populasi ikan dan pertumbuhan memiliki nilai variasi yang kecil namun dapat memiliki dampak yang signifikan terhadap hasil analisis populasi pada saat penting ketika tidak jelas apakah stok ikan yang ditargetkan oleh perikanan berbeda-beda dan untuk memperoleh titik referensi untuk manajemen berkelanjutan (Beverton dan Holt, 1957; ICCAT, 2013) Model pertumbuhan von Bertalanffy pada ikan tuna yang tertanfkap di Laut Aegea dan Ionia n adalah: L" $=94$, $7 \mathrm{~cm}, \mathrm{FL}, \mathrm{K}=0,258$, t0 = -1, 354 tahun Hubungan panjan berat antara jenis kelamin tidak berbeda model pertumbuhan allometrik $W=5,312 \times 10-5$ L 2,74 (Megalofonou,2000) sedangkan hasil penelitian ostics (2016) terhadap albacore di Atlantik Utara L" $=120,2$ $\mathrm{cm}, \mathrm{FL}, \mathrm{K}=0,21, \mathrm{t} 0=-1,62$ tahun. Menurut Kolody et al. (2015), ada tiga sumber data langsung yang dapat digunakan untuk memperkirakan persamaan pertumbuhan antara lain: (1) Distribusi frekuensi Catch length (CL) (2)Peningkatan pertumbuhan dari pelepasan tanda (tag) dan Penangkapan Kembali (3) Perkiraan usia dari struktur kapur/ kalsifikasi (bagian keras. Sendangkan Sampling berbasis panjang dapat menyebabkan bias dalam estimasi parameter pertumbuhan (Piner et al., 2016; Taylor et al., 2005; Schueller et al., 2014).

Bertambahnya ukuran ikan seiring dengan bertambahnya usia, maka dibuatlah model pertumbuhan ikan yang merupakan komponen kunci dari sebagian model penilian stok ikan. Memodelkan pertumbuhan ikan, atau bagaimana ikan bertambah besar seiring usia, adalah komponen kunci dari sebagian besar model penilaian stok ikan (Chris Francis R.I.C. 2016). Dan pengambilan data yang diukur harus acak dan pertumbuhan sangat sensentif terhadap kematian (Yi Xu et al., 2016).

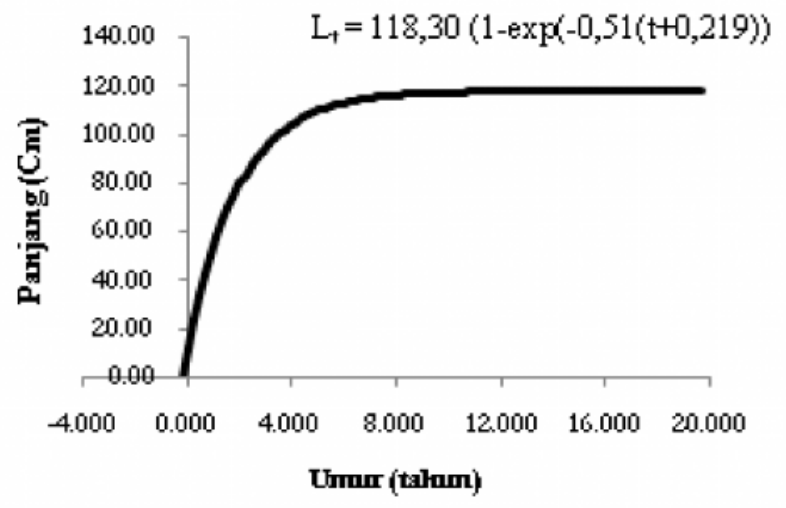

Gambar 3. Kurva pertumbuhan tuna albakora

Figure 3. Albakora tuna growth curve

\section{c. Length at First Capture (Lc)}

berdasarkan perhitungan diperoleh bahwa nilai Lc pada tuna albakorasebesar $101,61 \mathrm{~cm}$. FL Nilai Lc memberikan pengaruh terhadap nilai length at first mature (Lm) atau ukuran ikan pertama kali matang gonad. Lm total tuna albakora diketahui dari jurnal yaitu menurut Chen et al. (2005) adalah $90 \mathrm{~cm}$. Diduga albakora yang tertangkap mayoritas sudah matang gonad sehingga dapat ditarik kesimpulan jika kondisi stok masih terjaga/ baik. Akan tetapi dugaan ini belum kuat karena tidak dilakukan pengukuran Lm secara langsung saat penelitian.Panjang ikan pertama kali tertangkap lebih besar dari panjang ikan matang gonad (Lc $>$ Lm) maka tuna albakora dapat dikatakan sudah layak untuk ditangkap.

\section{d. Mortalitas dan Laju Eksplotasi}

Faktor utama yang mempengaruhi peningkatan stok adalah pertumbuhan dan rekrutmen, sedangkan yang mempengaruhi penurunan stok adalah mortalitas alami dan penangkapan. Dengan demikian data dan informasi mengenai pertumbuhan, rekrutmen, dan mortalitas dari stok ikan adalah faktor utama yang harus diketahui untuk pengelolaan populasi ikan di suatu perairan (Sudrajat, 2006).

Gambar 4 menunjukkan nilai laju mortalitas total (Z) tuna albakora sebesar 1,81, laju mortalitas alami (M) sebesar 0,8 serta laju mortalitas penangkapan (F) sebesar 1,01, sehingga diperoleh laju eksploitasi tuna albakorasebesar 0,56 atau 56\%. Nilai ini membuktikan bahwa tekanan penangkapan jauh lebih tingi dibandingkan kematian alami dikarenakan nilai mortalitas penangkapan lebih besar dari nilai 
mortalitas alami $(\mathrm{F}>\mathrm{M})$. Selain itu, nilai laju eksploitasi tuna albakora lebih dari nilai optimum sebesar 0,5 atau $50 \%$ sehingga kemungkinan tuna albakora yang didaratkan di pelabuhan Perikanan Nusantara (PPN) Prigi, Jawa Timur sudah overfishing. Menurut Gulland (1971), untuk menilai apakah suatu stok overfishing atau tidak, pada asumsi bahwa nilai optimal dari $\mathrm{E}$ (Eopt) adalah sama dengan 0,5. Penggunaan nilai $\mathrm{E}=$ 0,5 untuk rasio eksploitasi itu sendiri dengan asumsi bahwa hasil yang berkelanjutan dikatakan optimal ketika $\mathrm{F}=\mathrm{M}$.

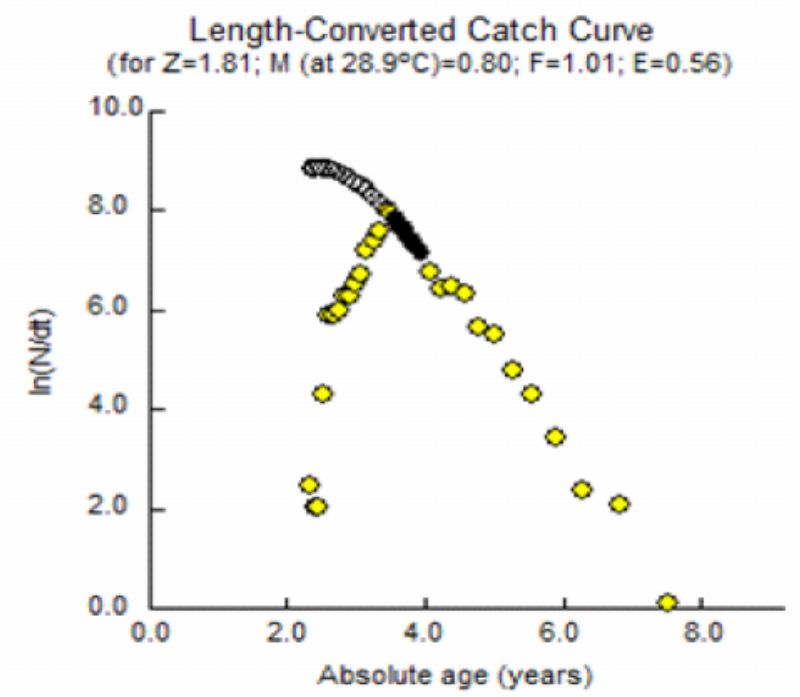

Gambar 4. Kurva mortalitas tuna albakora.

Figure 4. Albacora tuna mortality curve.

\section{e. Rekrutmen}

Rekrutmen dalam arti luas adalah penambahan individu baru dalam populasi atau tahap siklus hidup dalam populasi (Caley et al., 1996).

Gambar 5. dapat diasumsikan bahwa jumlah rekrutmen tertinggi terjadi pada bulan Maret yang merupakan puncak masuknya ikan ke area penangkapan. Diduga bahwa tuna albakorajuga mengalami rekrutmen setiap bulannya meskipun dengan jumlah yang tidak terlalu besar dan fluktuasi (Gambar 6).
Tahap sejarah hidup albakora di musim panas austral (Oktober sampai Maret) dan musim dingin (April sampai Agustus) dan kemungkinan migrasi mereka. Distribusi ini sesuai degan penelitian sebelumnya di Samudera Hindia dan Samudera Pasifik Selatan. Data frekuensi panjang albakora juga menunjukkan kehadiran ikan berukuran lebih kecil di selatan $30^{\circ} \mathrm{S}$ sementara yang lebih besar berada di utara (Dhurmeea et al., 2016).

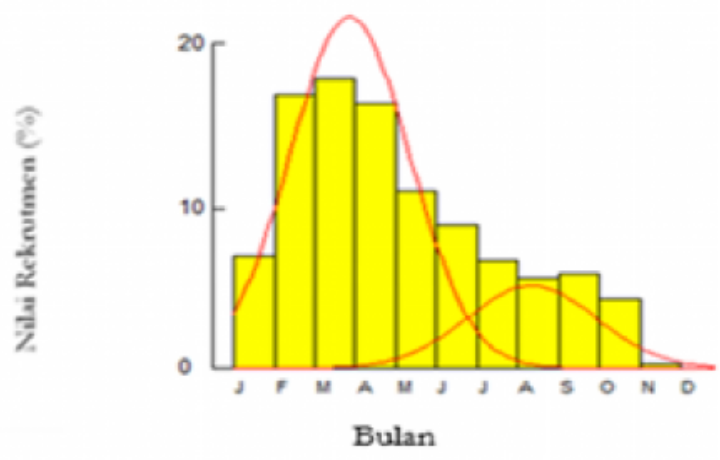

Gambar 5. Pola rekrutmen tuna albakora.

Figure 5. Pattern of albakora tuna recruitment. 


\section{f. Analisis Yield per Recruit $(Y / R)$ dan Biomass per Recruit (B/R)}

Perhitungan yield per recrut dan biomassa per recrut dilakukan menggunakan program aplikasi FISAT II yaitu knife-edge. Program ini menggunakan parameter diantaranya nilai $\mathrm{M}=0,8 ; \mathrm{K}=0,51 ; \mathrm{Lc}=101.61 \mathrm{~cm}$; $\mathrm{L} "=118,3$ dan $\mathrm{E}=0,56$. Rumus perhitungan $\mathrm{Y} / \mathrm{R}$ dan $\mathrm{B} / \mathrm{R}$ dimulai dari hasil nilai $\mathrm{M} / \mathrm{K}$ sebesar 1,57 dan $\mathrm{Lc} / \mathrm{L} "$
$=0,86$, sehingga didapatkan nilai yield per recrut $(\mathrm{Y} / \mathrm{R})$ sebesar 0,029 per tahun. Sedangkan nilai biomassa per recrut $(\mathrm{B} / \mathrm{R})$ sebesar 0,349 per tahun. Nilai $\mathrm{Y} / \mathrm{R}$ menunjukkan tuna albakorayang masuk ke perairan dan tertangkap oleh nelayan sebesar $2,9 \%$. Sedangkan nilai biomassa menunjukkan biomassa yang tersisa dari tuna albakora yang masuk ke perairan sebesar $34,9 \%$.

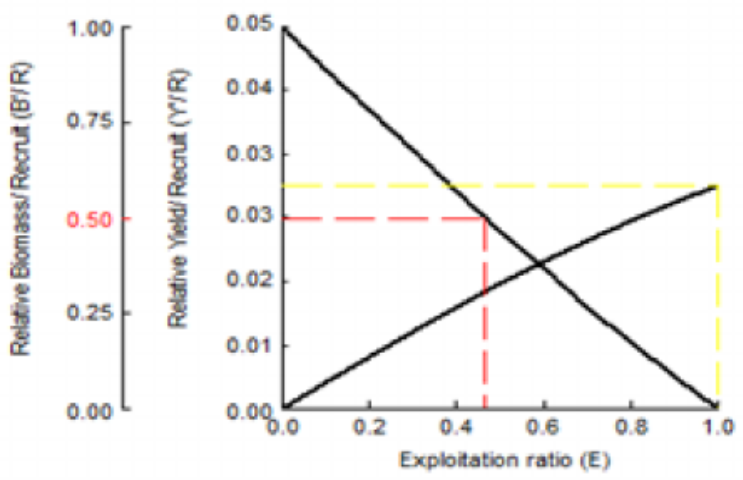

Gambar 6. Grafik nilai yield/ recruit dan biomass/ recruit.

Figure 6. Graph of yield / recruit and biomass / recruit values.

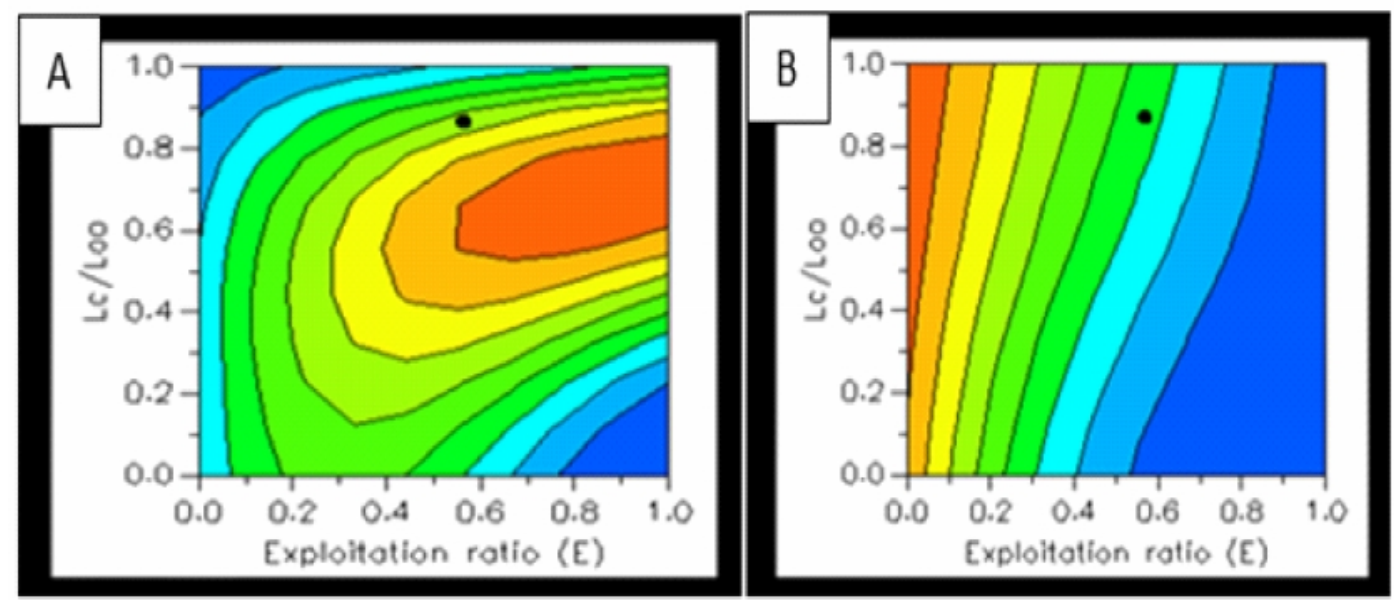

Gambar 7. (a) Grafik Isobar Y/R dan (b) B/R tuna albakora.

Figure 7. (a) Isobar $Y / R$ graph and (b) $B / R$ albakora tuna.

Perpotongan yang dihasilkan dari grafik $\mathrm{Y} / \mathrm{R}$ menunjukkan bahwa perikanan tuna albakoramengalami over-exploited dengan adanya titik hitam yang berada pada warna hijau kekuningan yang mendekati warna merah, sehingga tingkat pemanfaatan tuna albakora di perairan Prigi, Jawa Timur cukup tinggi. Pernyataan ini juga didukung oleh hasil perhitungan nilai laju eksploitasi (E) sebesar 0,56 yang menyatakan bahwa penangkapan cukup tinggi. Pada grafik $\mathrm{B} / \mathrm{R}$, titik hitam berada pada warna hijau sehingga menunjukkan stok ikan yang masih banyak karena tingkat pemanfaatan yang cukup tinggi.

\section{KESIMPULAN}

Hubungan panjang berat tuna albakora bersifat allometris negatif karena nilai $\mathrm{b}<3$ yaitu pada bulan Juli $b=2,031$, Agustus $b=2,24$, September $b=2,81$, Oktober $b=2,56$ dan November $b=2,89$. Parameter pertumbuhan tuna albakora L" $=118,3 \mathrm{~cm}, \mathrm{~K}=0,51$ per tahun, $\mathrm{t}_{\mathrm{o}}=-0,219$ tahun, $\mathrm{Lc}=101,6054 \mathrm{~cm}$, dengan mortalitas total $(\mathrm{Z})=1,81$, mortalitas alami $(\mathrm{M})=0,8$, mortalitas penangkapan $(\mathrm{F})=1,01$, laju eksploitasi $(\mathrm{E})=0,56$ yang menunjukkan overfishing. Nilai $\mathrm{Y} / \mathrm{R}=0,029$ per tahun dan nilai $\mathrm{B} / \mathrm{R}=0,349$ per tahun. 


\section{Ucapan Terima Kasih}

Penulis mengucapkan terima kasih kepada Jurnal Kelautan dan Perikanan Terapan.

\section{DAFTAR PUSTAKA}

Albaina, A., Iriondo, M., Velado, I., Laconcha, U., Zarraonaindia, I., Arrizabalaga, H., Pardo, M.A., ... Estonba, A. (2013). Single nucleotide polymorphism discovery in albacore and Atlantic blueûn tuna provides insights into worldwide population structure. Anim. Genet. 44, 678-692.

Alonso, C., Arrizabalaga, H., \& Restrepo, V.R. (2005). Contribution of a chapter on albacore tuna for the revised ICCAT field manual. Collect. Vol. Sci. Pap. ICCAT 58, 1646-1669.

Beverton, R.J.H., \& Holt, S.J. (1957). On Dynamics of Exploited Fish Populations. Chapman \& Hall, London, Facsimile reprint, 1993.

Cadima, E. L. (2003). Fish Stock Assessement Manual. FAO Fisheries Technical Paper. (393). 161p.

Caley, M.J., Carr, M. H., Hixon, M. A., Hughes, T. P., Jones, G. P., \& Menge, B.A. (1996). Recruitment and the Local Dynamics of Open Marine Populations. Annu. Rev. Ecol.Syst. 27:477-500.

Chen, I., Pei-Fen, L., \& Wann-Nian, T. (2005). Distribution of Albacore (Thunnus alalunga) in the Indian Ocean and Its Relation to Environmental Factors. Fisheries Oceanography. 14(1): 71-80.

Chris Francis R.I.C. (2016). Growth in age-structured stock assessment Fisheries Research 180 (2016) 77-86.

Collette, B. B., \& Nauen, C.E. (1983). Scrombids of the World: an Annotated and illustrated Catalogue. FAO Species Catalogue of Tunas, Mackerels, Bonitos, and Related Species Known to Date.(2)125. $137 \mathrm{p}$.

Consoli, P., Romeo, T., Battaglia, P., Castriota, L., Esposito, V., \& Andaloro, F. (2008). Feeding habits of the albacore tuna Thunnus alalunga (Perciformes, Scombridae) from central Mediterranean Sea. Mar. Biol. 155, 113-120.

Dhurmeea Z., Emmanuel, C., Augustin E., Assan C., Nikolic, N., Bourjea, J., West W., Appaddo, C., Nathalie, B.C. (2016). Morphometrics of albacore tuna (Thunnus alalunga) in the Western Indian Ocean. Victoria Mahé : CTOI, (IOTC-2016WPTmT06-28), 18 p.

Gayanilo., Sparre, P., \& Pauly, D. (2005). FISAT II User's Guide. Food and Agriculture Organization of The United Nations. Rome.

Gulland, J. A. (1971). The Fish Resourouthe Atlantic Albacore - a Revision after the Reelation of Otolith Daily Ring Counts. ICCAT. 60(2): 443-456.
Haritz, A., Dufour, F., Kell, L., Merino, G., Ibaibarriaga, L., Chust, G., Irigoien, X., ... Bonhomeau, S. (2015). Global habitat preferences of commercially valuable tuna. Deep-Sea Research II 113 (2015) 102 112.

ICCAT. (2013). Report of the 2013 ICCAT North and South Atlantic albacore data Preparatory meeting. Col. Vol. Sci. Pap. ICCAT 70 (3), 717-829 https:/ /www. iccat.int/Documents/CVSP/CV070 2014/n 3/ CV070030717.pdf

Joseph, J. (2003). Managing fishing capacity of the world tuna fleet. FAO Fisheries Cicular. No. 982. FAO, Rome, 67 pp.

Kolody, D. S., Paige, E., Richard, M., \& Hillary. (2016). Modelling Growth in Tuna RFMO Stock Assessment: Current Approaches and Challenges. Fisheries Research180, Pages 177-193

Megalofonou P. (2000). Age and growth of Mediterranean albacore Journal of Fish Biology (2000) 57, 700-715 doi:10.1006/jfbi.2000.1345.

Ortiz de Záratea., \& Babcock, E.A. (2016). Estimating individual growth variability in albacore (Thunnus alalunga) from the North Atlantic stock: Aging for assessment purposes. Fisheries Research 180 (2016) 54-66.

Schueller, A.M., Williams, E.H., \& Cheshire, R.T. (2014). A proposed, tested, and applied Adjustment to account for bias in growth parameter estimates due to selectivity. Fisheries Research 158 (2014) 26-39

Sibert, J., \& Hampton, J. (2003). Mobility of tropical tunas and the implications for fishery management. Mar. Policy 27, 87-95.

Sibert, J., Hampton, J., Kleiber, P., \& Maunder, M. (2006). Biomass, size, and trophic status of top predators in the Pacific Ocean. Science ; 314 , 1773-177.

Sparre, P. E., Ursin \& Siebren, C. V. (1989). Introduction To Tropical Fish Stock Assessment : Part 1 Manual. FAO Fisheries Technical Paper 306/1. Rome.

Pauly, D. (1983). Some Simple Methods for the Assessment of Tropical Fish stocks. FAO Fish. Tech. Pap. (234): 52p.

Piner, K.R., Lee, H.-H., \& Maunder, M.N. (2016). Evaluation of using random at length Observations and an equilibrium approximation of the population age structure in utting the von Bertalanffy growth function. Fisheries Research 180 (2016) 128-137

Taylor, N.G., Walters, C.J., \& Martell, S.J.D. (2005). A new likelihood for simultaneously Estimating von Bertalanffy growth parameters, gear selectivity, and natural and ûshing mortality. Can. J. Fish. Aquat. Sci. 62, 215-223. 
Yi Xu., Steven L.H., Teo., Kevin, R., Piner, Kuo-Shu Chen, R.J., \& David Wells. (2016). Using an approximate length-conditional approach to esti- mate von Bertalanffy growth parameters of North Paciûc albacore (Thunnus alalunga). Fisheries Research.138-146. 